\title{
PENGEMBANGAN BUKU SAKU EKONOMI DENGAN KONSEP MIND MAPPING UNTUK MENINGKATKAN MOTIVASI BELAJAR PESERTA DIDIK
}

\author{
Fines Anita Putri Premianti \\ Universitas Negeri Surabaya, finespremianti16080554016@mhs.unesa.ac.id
}

\section{DOI}

https://doi.org/10.26740/jupe.v9n3.p114$\underline{120}$

\author{
Article history \\ Received \\ 01 August 2021 \\ Revised \\ 12 August 2021 \\ Accepted \\ 13 August 2021
}

\section{How to cite}

Preminianti, F.A.P. (2021). Pengembangan Buku Saku Ekonomi dengan Konsep Mind Mapping Untuk Meningkatkan Motivasi Belajar Peserta Didik. Jurnal Pendidikan Ekonomi (JUPE), 9(3), 114-120.

https://doi.org/10.26740/jupe.v9n3.p114$\underline{120}$

Kata Kunci: Buku Saku Ekonomi, Mind Mapping, Motivasi Belajar, Pendukung Bahan Ajar

Keywords: Economic Pocket Book, Mind Mapping, Learning Motivation, Supporting Teaching Materials

\section{Corresponding author}

Fines Anita Putri Premianti

finespremianti16080554016@mhs.unesa.ac.id

\begin{abstract}
Abstrak
Penelitian pengembangan (R\&D) ini bertujuan untuk meningkatkan motivasi belajar ekonomi peserta didik serta mengetahui tingkat kelayakan, kepraktisan, dan keefektifan penggunaan buku saku menggunakan metode pengembangan ADDIE. Pengumpulan data dilakukan dengan melakukan pengamatan, wawancara, dan pemberian angket. Pengukuran motivasi belajar dilakukan sebelum dan sesudah pemberian buku saku ekonomi dengan menggunakan angket. Hal tersebut juga digunakan untuk mengetahui kepraktisan dan efektivitas penggunaan buku saku. Data dianalisa secara deskriptif kuantitatif guna mendapatkan deskripsi kelayakan materi, media, grafis, serta respon peserta didik dan perubahan motivasi belajar partisipan. Hasil penilaian kelayakan menunjukkan kategori sangat layak dengan persentase validasi 90,6\% dari ahli materi; 93,3\% dari ahli media; dan $84 \%$ dari ahli grafis. Selain itu, partisipan mengungkapkan bahwa buku saku dinilai praktis dan mampu meningkatkan motivasi belajar ekonomi peserta didik sebesar 3,9\% dengan hasil uji analisis t sebesar 0,01 .
\end{abstract}

\section{Abstract}

Based on the students' low motivation to learn economics, this study seeks to develop an economics pocketbook. Using the ADDIE method, this development research $(R \& D)$ aims to increase students' motivation to learn economics and to determine the level of feasibility, practicality, and effectiveness of using pocketbook. Data was collected by observing, interviewing, and giving questionnaires. Measurement of learning motivation was carried out before and after giving the economic pocketbook using a questionnaire. It is also used to determine the practicality and effectiveness of using pocketbooks. The data were analyzed descriptively quantitatively in order to obtain a description of the feasibility of the material, media, graphics, as well as student responses and changes in participants' learning motivation. The results of the feasibility assessment show a very feasible category with a validation percentage of $90.6 \%$ from material experts; $93.3 \%$ of media experts; and $84 \%$ of graphic experts. In addition, participants revealed that pocket books were considered practical and able to increase students' motivation to learn economics by $3.9 \%$ with a $t$-test result of 0,01 . 


\section{PENDAHULUAN}

Pendidikan merupakan fase penting dalam proses perubahan sikap dan perilaku seseorang atau sekelompok agar menjadi dewasa melalui pengajaran dan pelatihan (KBBI, 2016). Kurikulum merupakan aspek yang berkontribusi dalam peningkatan kualitas pendidikan. Hal ini dikarenakan kurikulum mencakup tujuan, materi pembelajaran, isi, dan cara dalam pelaksaan kegiatan pembelajaran sesuai rencana dan tujuan pendidikan yang telah ditetapkan (Presiden Republik Indonesia, 2005).

Kurikulum 2013 adalah lanjutan dari kurikulum KTSP (kurikulum tingkat satuan dasar) yang meliputi kompetensi pengetahuan, sikap, dan keterampilan di mana peserta didik diminta untuk aktif dalam proses diskusi ataupun presentasi yang berlangsung dalam proses pembelajaran, memahami materi, dan memiliki sikap santun yang tinggi. Penggunaan kurikulum juga harus diimbangi dengan penggunaan pendukung bahan ajar yang sesuai dengan karakter peserta didik. Hal ini untuk memudahkan peserta didik dalam memahami pelajaran.

Pada Sekolah Menengah Atas (SMA) penggunaan bahan ajar seringkali hanya terbatas pada modul, lembar kerja peserta didik (LKPD), slide, atau buku teks yang diberikan pemerintah. Karakteristik modul ataupun buku teks yang tebal, berat, dan memiliki kalimat panjang seringkali menyebabkan peserta didik merasa kurang tertarik untuk mempelajarinya, sedangkan slide hanya digunakan sebagian sekolah karena enggannya guru dalam membuatnya meskipun sarana dan prasarana di sekolah telah tersedia dan mampu mendukung penyajian bahan ajar tersebut. Menurut Prastowo (dalam Agustien \& Agung, 2012) mengungkapkan banyaknya pendidik yang cederung menggunakan bahan ajar yang instan tanpa ada usaha merencanakan, menyiapkan, dan menyusun sendiri. Hal ini yang seringkali membuat peserta didik kurang tertarik pada suatu mata pelajaran. Penggunaan bahan ajar yang tepat pada pembelajaran dapat memberikan beberapa manfaat, yakni memperjelas penyajian pesan agar tidak terlalu verbal, menimbulkan motivasi belajar, dan memungkinkan peserta didik belajar sendiri (Azhar, 2011).

Berdasarkan observasi awal, permasalahan yang ditemukan adalah tidak adanya semangat belajar ekonomi yang dimiliki oleh peserta didik kelas X IPA MAN Sidoarjo. Wawancara pendahuluan yang telah dilakukan memperoleh fakta bahwa pada kegiatan belajar mengajar mata pelajaran ekonomi hanya dilakukan dengan metode ceramah tanpa adanya buku penunjang karena buku ekonomi dikhususkan untuk kelas IIS. Hal ini menyebabkan peserta didik jurusan IPA menemui kendala dalam proses pembelajaran yang dianggap cenderung membosankan. Sehingga absennya buku penunjang mata pelajaran ekonomi berpengaruh terhadap motivasi belajar peserta didik jurusan IPA. Penelitian ini berfokus pada peserta didik jurusan IPA, dimana mata pelajaran ekonomi hanya merupakan mata pelajaran peminatan sehingga cenderung dianggap remeh. Selain itu, peneliti bertujuan mengenalkan mata pelajaran ekonomi dengan menggunakan buku saku dengan konsep mind mapping yang teruji terkait kelayakan, kepraktisan, dan keefektifan khususnya bagi peserta didik jurusan IPA.

Buku saku berkonsep mind mapping menjadi alternatif penunjang mata pelajaran. Hal ini karena buku saku berisikan materi-materi singkat, tampilan menarik, mudah dibawa kemana saja dan dapat digunakan peserta didik kapan saja (Sulistyani dalam Agustien \& Agung, 2012). Kondisi tersebut membuat waktu yang dibutuhkan peserta didik untuk mengetahui esensi dari sebuah informasi menjadi lebih efisien (Aini dalam Agustien \& Agung, 2012).

Metode pencatatan mind mapping digunakan untuk memudahkan brainstorming karena ide dan gagasan yang sulit dipahami menjadi lebih mudah. Selain itu, pencatatan menggunakan mind mapping juga selaras dengan kurikulum 2013 yang berkaitan dengan keterampilan dan merujuk pada kreativitas peserta didik dalam menerima materi pembelajaran.

Kegiatan belajar dapat berlangsung tanpa adanya dorongan guru ataupun orang tua, itu artinya bahwa peserta didik belajar karena keinginannya sendiri atau motivasi yang muncul dari dalam diri. Motivasi belajar cenderung meningkat apabila tidak ada gangguan yang membuatnya turun seperti gangguan teman yang kurang baik dan situasi lingkungan. Motivasi belajar akan muncul karena adanya tujuan yang merupakan respon adanya kebutuhan (Sadiman, 2014).

Penelitian ini dilakukan karena selaras dengan penelitian oleh Qurrota'Aini \& Sukirno (2013) yang berhasil mengembangkan buku saku untuk meningkatkan motivasi belajar peserta didik dengan rata-rata skor sebesar 5,64\%. Penelitian lain oleh Suhaimi \& Hakim (2013) menunjukkan bahwa buku saku efektif mendorong peningkatan motivasi belajar sebesar $93 \%$ dari penilaian kelayakan peserta didik. Selain itu Pramika \& Widalismana (2018) mengungkapkan dalam penelitiannya buku saku mendorong keaktifan belajar peserta didik dengan skor $93 \%$ dari penilaian kelayakan peserta didik.

Penelitian ini berupaya mengembangkan buku saku ekonomi dengan konsep mind mapping yang bertujuan untuk meningkatkan motivasi belajar peserta didik kelas $\mathrm{X}$ jurusan IPA serta mengetahui kelayakan, kepraktisan, dan keefektifan pengunaan buku saku sebagai pendukung bahan ajar. Konsep mind mapping yang digunakan dalam pengembangan buku saku berguna untuk memanfaatkan cara otak bekerja sehingga dapat memudahkan peserta didik dalam memahami materi yang diberikan. Selain itu, 
buku saku juga disajikan dengan tampilan yang mudah dipahami daripada buku paket maupun LKPD. Analisis kelayakan dari pendukung bahan ajar dilakukan sebelum adanya uji coba secara terbatas untuk mengetahui kontribusi dalam meningkatkan motivasi belajar ekonomi peserta didik.

\section{METODE}

Jenis penelitian yang digunakan adalah Research and Development (R\&D) yang dilakukan dengan membuat suatu produk dan mengukur efektivitas (Sugiyono, 2014). Model pengembangan yang digunakan adalah model ADDIE yang terdiri dari lima tahapan. Proses tahapan tersebut digambarkan dalam diagram berikut :

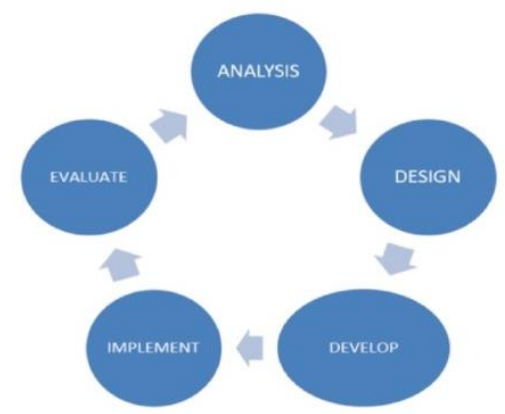

Gambar 1. Tahapan Penelitian ADDIE

Sumber : Rayanto \& Sugianti (2020)

Prosedur pengembangan dalam penelitian ini antara lain : (1) Analysis, dilakukan dengan melakukan pengamatan kelas, wawancara, dan analisa kebutuhan peserta didik; (2) Design, proses perancangan dimana peneliti melakukan rancangan konsep awal yang berkaitan dengan materi dan mind mapping serta perancangan instrumen penilaian kelayakan materi, kelayakan media, kelayakan grafis, kepraktisan, dan keefektifan; (3) Development, tahap pengembangan dilakukan dengan penyusunan desain prototipe yang kemudian akan diuji kelayakannya oleh beberapa ahli; (4) Implementation, tahap implementasi dilakukan dengan uji coba secara terbatas kepada 20 peserta didik kelas X IPA 3 Peminatan MAN Sidoarjo, dan (5) Evaluation, evaluasi produk dilakukan berdasarkan saran dan masukan dari ahli materi, media, dan grafis.

Desain uji coba dalam pengembangan ini menerapkan One Group Pretest-Posttest yang dilakukan hanya terhadap satu kelas tanpa adanya kelas pembanding. Hasil uji coba akan dilakukan dengan membandingkan hasil pretest motivasi belajar sebelum menggunakan produk buku saku dan hasil posttest motivasi belajar setelah menggunakan buku saku. Uji coba terbatas pada kelompok kecil terdiri dari 10-20 orang peserta didik yang telah mewakili populasi target (Sadiman, 2014). Subjek penelitian direkrut menggunakan teknik insidental sampling di mana sampel dipilih dari individu yang ditemui di lapangan dan sesuai dengan kriteria yang telah ditetapkan (Sugiyono, 2014). Individu yang dilibatkan dalam kelompok uji sejumlah 20 peserta didik kelas $\mathrm{X}$ IPA 3 Peminatan MAN Sidoarjo.

Instrumen yang digunakan dalam proses pengumpulan data, yaitu lembar telaah ahli media, materi, dan grafis yang terdiri dari beberapa butir pernyataan yang akan dinilai oleh para ahli untuk mendapatkan saran ataupun masukan terkait bahan ajar dalam proses pengembangan; lembar validasi ahli materi, ahli media, dan ahli grafis yang akan divalidasi oleh beberapa ahli yang digunakan untuk mengetahui persentase kelayakan bahan ajar yang dikembangkan; lembar angket motivasi belajar ekonomi peserta didik yang digunakan untuk mengetahui efektivitas dan peningkatan motivasi belajar ekonomi setelah menggunakan produk buku saku; dan lembar respon yang digunakan untuk mengetahui kepraktisan penggunaan buku saku ekonomi sebagai pendukung bahan ajar oleh peserta didik.

Analisa data pengembangan dilakukan dengan teknik analisa deskriptif kuantitatif. Data kuantitatif didasarkan pada validasi para ahli dengan skala 1-5 yang kemudian akan diubah menjadi persentase dan diinterpretasikan berdasarkan kriteria kelayakan validasi materi, media, dan grafis. Selain itu, data kuantitatif juga didapatkan dari hasil respon peserta didik yang diukur menggunakan skala Guttman yang nantinya akan diinterpretasikan dengan kriteria interpretasi yang sama.

Respon peserta didik juga digunakan untuk mengukur peningkatan motivasi belajar ekonomi melalui angket yang diadaptasi dari angket Tuan (dalam Susanti, 2019). Angket motivasi didasarkan pada aspek instrinsik dengan indikator kepercayaan diri, nilai pembelajaran, serta tujuan pencapaian dan aspek ekstrinsik den strategi pembelajaran aktif serta belajar stimulasi lingkungan .

Angket motivasi belajar akan dianalisis menggunakan uji $\mathrm{t}$ (paired sample test) yang bertujuan untuk mengetahui apakah terdapat peningkatan motivasi belajar peserta didik setelah dilakukan uji coba serta digunakan untuk mengetahui apakah pendukung bahan ajar yang digunakan efektif dalam peningkatan motivasi belajar peserta didik. Peneliti juga menggunakan data kualitatif yang didapatkan dari hasil telaah para ahli, berupa saran ataupun masukan yang digunakan sebagai acuan dalam perbaikan dan evaluasi pengembangan bahan ajar.

\section{HASIL}

Hasil penelitian pengembangan akan dijabarkan berdasarkan tahapan prosedur penelitian ADDIE. Pertama tahap analisa digunakan untuk mengetahui permasalahan dasar yang ada pada proses pembelajaran guna memastikan bahwa produk yang dikembangkan dapat memenuhi kebutuhan peserta didik. Hasil analisa 
menunjukkan bahwa peserta didik khususnya kelas IPA cenderung menganggap remeh mata pelajaran ekonomi. Hal ini didukung dengan tidak adanya bahan ajar penunjang sehingga peserta didik hanya mendapat materi dari yang disampaikan oleh penddik. Selain itu keterbatasan buku penunjang di perpustakaan yang mengharuskan peserta didik berusaha untuk meminjam buku dari kelas lain. Penentuan batasan penyajian materi juga diperlukan, dalam pengembangan ini peneliti memilih menggunakan materi kelas $\mathrm{X}$ mata pelajaran ekonomi semester 1 dengan fokus kelas IPA yang mempelajari ekonomi sebagai mata pelajaran peminatan. Maka dari itu, penelitian pengembangan buku saku ekonomi dengan konsep mind mapping menjadi penting untuk dilakukan.

Tahap kedua merupakan tahap perancangan proses merancang atau membuat konsep desain pendukung bahan ajar berdasarkan permasalahan yang telah dipaparkan pada tahap analisa. Tahap perancangan meliputi penyusunan kerangka awal buku yang dilakukan menggunakan microsoft power point dan disusun desainnya menggunakan aplikasi desain, penyusunan konsep penyajian materi serta penempatan mind mapping, perancangan instrumen telaah dan validasi para ahli terkait kelayakan isi dan perancangan angket untuk mengetahui kepraktisan dan efektivitas penggunaan buku saku. Berikut contoh kerangka awal dan desain awal yang telah dilakukan:

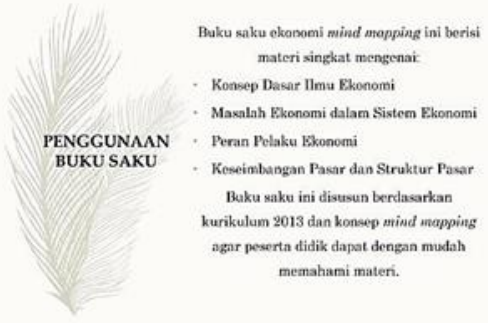

Gambar 2. Kerangka Awal Halaman Petunjuk Penggunaan

Sumber : Peneliti (2021)

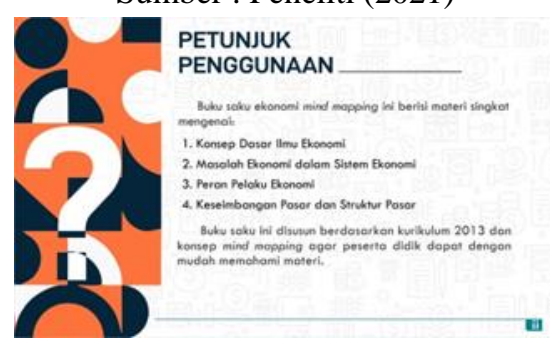

Gambar 3. Desain Awal Halaman Petunjuk Penggunaan Sumber : Peneliti (2021)

Pada buku saku ekonomi juga disajikan peta konsep yang menunjukkan seluruh indikator yang akan dipelajari guna memudahkan peserta didik mengetahui materi yang ada pada buku saku. Contoh penyajian peta konsep :

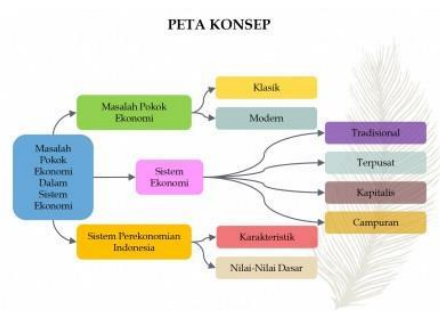

Gambar 4. Kerangka Awal Halaman Peta Konsep Sumber : Peneliti (2021)

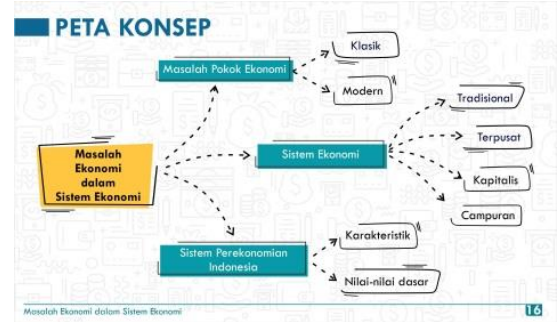

Gambar 5. Desain Awal Halaman Peta Konsep

Sumber : Peneliti (2021)

Tahap pengembangan yang merupakan tahap ketiga dari proses penelitian pengembangan akan dilakukan penyusunan desain produk prototipe yang kemudian akan diuji kelayakannya oleh beberapa ahli. Pada tahap ini juga menjelaskan salah satu tujuan diadakannya penelitian pengembangan. Berikut merupakan beberapa contoh tampilan buku saku ekonomi dengan konsep mind mapping:

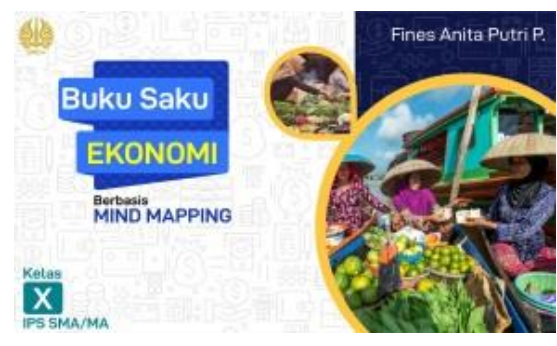

Gambar 6. Tampilan Halaman Sampul Sumber : Peneliti (2021)

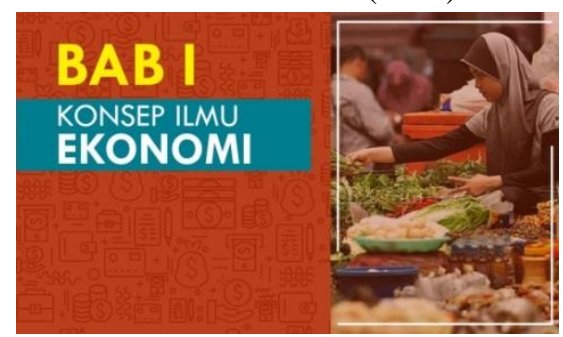

Gambar 7. Tampilan Halaman Awal Bab Sumber : Peneliti (2021)

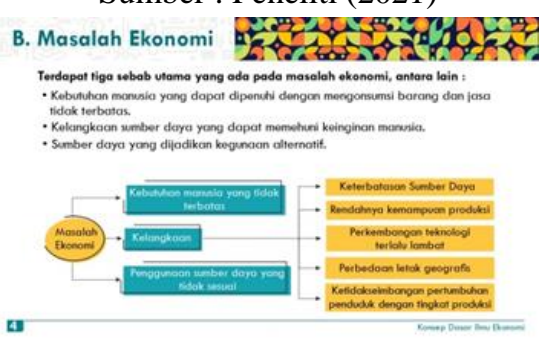

Gambar 8. Tampilan Penyajian Materi dan Mind Mapping 


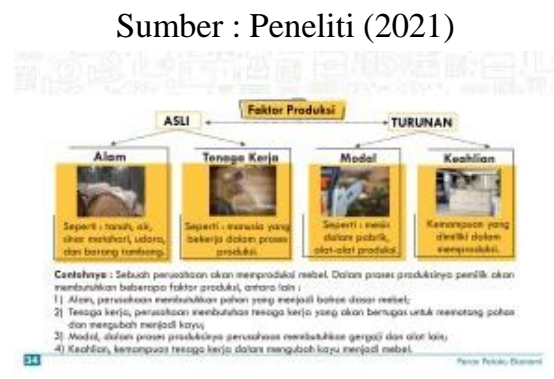

Gambar 9. Tampilan Penyajian Materi dan Mind Mapping Sumber : Peneliti (2021)

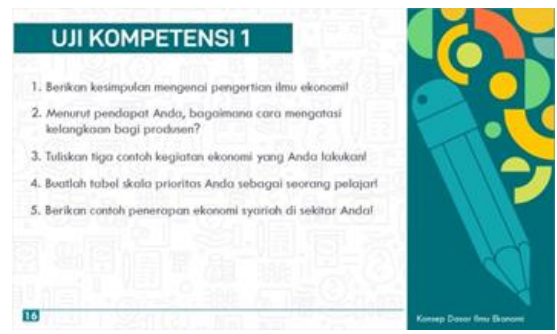

Gambar 10. Tampilan Halaman Latihan Soal

Sumber : Peneliti (2021)

Setelah buku saku ekonomi dengan konsep mind mapping dikembangkan, langkah selanjutnya adalah melakukan telaah dan validasi ahli, yang kemudian akan ditinjau ulang dan diperbaiki sebelum dilakukan uji coba terbatas. Telaah dan validasi pertama dilakukan oleh ahli materi yang menilai kelayakan dari aspek kualitas isi dan tujuan, instruksional, dan teknis.

Tabel 2. Validasi Ahli Materi

\begin{tabular}{lcc}
\hline \multicolumn{1}{c}{ Aspek Penilaian } & Total Skor & Persentase \\
\hline Kualitas Isi dan Tujuan & 27 & $90 \%$ \\
Kualitas Instruksional & 22 & $88 \%$ \\
Kualitas Teknis & 19 & $95 \%$ \\
\hline Rerata Validasi Materi & 68 & $90,6 \%$ \\
\hline
\end{tabular}

Tabel 3. Validasi Ahli Media

\begin{tabular}{lcc}
\hline \multicolumn{1}{c}{ Aspek Penilaian } & Total Skor & Persentase \\
\hline Kualitas Isi dan Tujuan & 15 & $100 \%$ \\
Kualitas Instruksional & 15 & $100 \%$ \\
Kualitas Teknis & 14 & $93,3 \%$ \\
\hline Rerata Validasi Media & 44 & $97,7 \%$ \\
\hline
\end{tabular}

Tabel 4. Validasi Ahli Grafis

\begin{tabular}{lcc}
\hline \multicolumn{1}{c}{ Aspek Penilaian } & Total Skor & Persentase \\
\hline Kualitas Teknis & 42 & $84 \%$ \\
\hline Rerata Validasi Grafis & 42 & $84 \%$ \\
\hline
\end{tabular}

Berdasarkan hasil validasi yang telah dipaparkan pada tabel di atas, tabel 2 menunjukkan bahwa validasi materi memperoleh rata-rata sebesar 90,6\% dengan kategori sangat layak dengan saran berupa penambahan gambar pada beberapa materi agar penyajian menjadi lebih interaktif. Pada validasi media yang ditunjukkan pada tabel 3 skor rata-rata yang didapatkan sebesar 97,7\% dikategorikan sangat layak dengan saran berupa pengurangan elemen grafis pada desain buku saku agar tidak menganggu proses membaca peserta didik. Validasi kegrafikan ditunjukkan pada tabel 4 dengan skor rata-rata sebesar $84 \%$ yang menunjukkan kategori sangat layak dengan saran berupa pengurangan uraian dalam mind map agar sesuai dengan konsep yang praktis. Berdasarkan skor validasi yang diperoleh dari para ahli dapat disimpulkan bahwa buku saku dengan konsep mind mapping layak untuk dilakukan uji coba.

Tahap keempat merupakan tahap implementasi yaitu melakukan uji coba terbatas yang bertujuan untuk mengetahui tingkat kepraktisan dan keefektifan dari penggunaan buku saku ekonomi dengan konsep mind mapping sebagai pendukung bahan ajar. Uji coba terbatas melibatkan 20 orang peserta didik kelas X IPA 3 Peminatan MAN Sidoarjo yang dilakukan secara daring. Kepraktisan penggunaan buku saku didapatkan dari hasil respon peserta didik setelah menggunakan buku saku dalam memahami materi. Berdasarkan hasil respon peserta didik lihat tabel 5 yang didapatkan setelah uji coba terbatas memperoleh rata-rata persentase sebesar 92,2\% yang dikategorikan sangat layak jika digunakan dalam proses pembelajaran.

Tabel 5. Rekapitulasi Respon Peserta Didik

\begin{tabular}{lcc}
\hline \multicolumn{1}{c}{ Aspek Penilaian } & Total Skor & Persentase \\
\hline Kualitas Teknis & 55 & $91,6 \%$ \\
Kualitas Instruksional & 108 & $90 \%$ \\
Kualitas Isi dan Tujuan & 40 & $100 \%$ \\
\hline Rerata Validasi Media & 203 & $92,2 \%$ \\
\hline
\end{tabular}

Keefektifan penggunaan buku saku ekonomi dengan konsep mind mapping sebagai pendukung bahan ajar didapatkan dari hasil peningkatan motivasi belajar ekonomi peserta didik saat dilakukan uji coba terbatas di mana peserta didik akan mengisi angket pretest-posttest yang berkaitan dengan motivasi belajar ekonomi dalam bentuk google form. Berdasarkan uji coba terbatas yang dilakukan didapatkan total persentase pretest sebesar 79\% dan total persentase posttest sebesar $82,9 \%$. Hal ini menunjukkan terdapat peningkatan motivasi belajar peserta didik sebesar 3,9\%. Selain itu, dari uji analisis $\mathrm{t}$ menunjukkan hasil signifikansi sebesar $0,01<0,05$ sehingga bahan ajar buku saku ekonomi dengan konsep mind mapping dapat dikatakan efektif dalam membantu meningkatkan motivasi belajar peserta didik.

Tahap terakhir adalah tahap evaluasi yang guna memberikan perbaikan terhadap pendukung bahan ajar yang telah dikembangkan. Evaluasi dalam penelitian ini dilakukan pada tahap ketiga yaitu dari hasil telaah para ahli berupa saran dan masukan yang kemudian akan dilakukan revisi dan perbaikan. Uji coba produk yang 
dilakukan juga masih dilakukan secara terbatas sehingga perlu adanya perluasan uji coba hingga dapat digunakan sebagai acuan penggunaan dalam proses pembelajaran.

\section{PEMBAHASAN}

\section{Kelayakan Buku Saku Ekonomi Dengan Konsep Mind Mapping}

Kelayakan buku saku ekonomi dengan konsep mind mapping didasarkan pada validasi dan telaah dari ahli media, materi, dan grafis. Berdasarkan validasi materi yang telah dilakukan, diperoleh rata-rata kualitas isi dan tujuan sebesar 90\%, kualitas instruksional sebesar $88 \%$, dan kualitas teknis sebesar 95\%. Rata-rata hasil validasi kelayakan materi dari seluruh aspek sebesar 90,6\% dengan kategori "sangat layak" sehingga dapat digunakan pada proses pembelajaran. Selanjutnya validasi media, diperoleh rata-rata kualitas isi dan tujuan sebesar $100 \%$, kualitas instruksional sebesar 100\%, dan kualitas teknis sebesar 93,3\%. Rata-rata hasil validasi kelayakan media dari semua aspek sebesar 93,3\% dengan kriteria "sangat layak" dan dapat digunakan pada proses pembelajaran. Hasil validasi grafis yang dilakukan. Diperoleh rata-rata total sebesar $84 \%$ yang dikategorikan "sangat layak". Sehingga disimpulkan bahwa buku saku ekonomi dengan konsep mind mapping layak digunakan dalam proses pembelajaran.

Selaras dengan hasil penelitian pengembangan oleh Santi, Haryono, \& Sunaryanto (2017) yang mengungkapkan bahwa buku saku ekonomi dapat digunakan dalam kegiatan pembelajaran tanpa revisi. Penelitian Davies (2011) menyatakan bahwa umumnya lebih mudah jika mengingat menggunakan diagram daripada deskripsi, selain itu mind map dapat meningkatkan pemikiran kreatif dan mendorong brainstorming. Pramika \& Putri (2013) mengungkapkan dalam penelitiannya bahwa buku saku sebagai media pembelajaran berpotensi memberikan dampak positif terhadap hasil belajar mahasiswa dan meningkatkan belajar mahasiswa.

\section{Kepraktisan Buku Saku Ekonomi Dengan Konsep} Mind Mapping

Kepraktisan penggunaan buku saku ekonomi diketahui dari rekapitulasi angket respon peserta didik yang diberikan setelah peserta didik menggunakan buku saku, didapatkan hasil jawaban "Ya" sebanyak 203 dan jawaban "Tidak" sebanyak 17 dari total 220 jawaban dengan 11 item pertanyaan. Berdasarkan hasil analisis respon peserta didik diperoleh hasil rata-rata dengan persentase sebesar 92,2\% yang dikategorikan "Sangat Layak". Hal ini didukung dengan tanggapan peserta didik yang menilai konsep mind mapping yang diterapkan dirasa sangat memudahkan peserta didik dalam memahami pelajaran.
Kondisi tersebut memotivasi peserta didik untuk mempelajari mata pelajaran ekonomi.

Selaras dengan penelitian yang dilakukan oleh Saputra, Abidin, Ansari, \& Hidayat (2018) bahwa media pembelajaran berbasis buku saku dinilai praktis berdasarkan tanggapan dari pengguna dengan hasil sebesar $86,32 \%$. Hal ini juga didukung penggunaan mind map yang relevan, praktis, dan efektif digunakan dalam proses pendidikan (Bystrova \& Larionova, 2015; Stokhof, de Vries, Bastiaens, \& Martens, 2019).

\section{Keefektifan Penggunaan Buku Saku Ekonomi Dengan Konsep Mind Mapping}

Keefektifan penggunaan buku saku ekonomi diketahui dari hasil uji coba yang menunjukkan peningkatan motivasi belajar ekonomi peserta didik yang diukur menggunakan angket pretest motivasi belajar, diberikan sebelum peserta didik menggunakan buku saku dan angket posttest motivasi belajar, diberikan setelah peserta didik menggunakan buku saku. Hasil uji coba menunjukkan total skor pretest sebesar 1265 dalam persentase $79 \%$ dan total skor posttest sebesar 1317 dalam persentase $82,9 \%$. Hal ini menunjukkan bahwa penggunakan buku saku efektif meningkatkan motivasi belajar peserta didik sebesar 3,9\%. Selain itu, uji analisis t menunjukkan hasil signifikansi sebesar 0,01 yang lebih kecil dari $p$ value $(0,05)$ sehingga dapat diartikan bahwa buku saku efektif meningkatkan motivasi belajar ekonomi peserta didik.

Peserta didik menilai desain buku saku yang telah dikembangkan tidak membosankan ataupun monotone ditunjukkan dengan adanya warna yang bervariasi. Hal ini pun menjadi salah satu keunggulan buku saku yang telah dikembangkan. Selain itu, materi yang dijabarkan dalam mind mapping dibuat secara ringkas dan jelas sehingga dapat membantu peserta didik untuk memahami serta meningkatkan motivasi belajar ekonomi.

Produk buku saku tentunya masih memiliki banyak kelemahan. Diantaranya adalah materi terbatas pada KD 3.1 sampai dengan 3.4 kelas X mata pelajaran ekonomi, belum adanya soal dalam buku saku yang mampu membantu menilai sejauh mana pemahaman peserta didik, uji coba produk yang dilakukan secara terbatas juga belum dapat digunakan sebagai acuan umum, dan masih banyak lagi. Sehingga muncul peluang bagi peneliti lain untuk melakukan penelitian lebih lanjut terkait dengan uji coba yang lebih luas serta materi yang lebih lengkap.

Penelitian ini selaras dengan yang dilakukan oleh Qurrota'Aini \& Sukirno (2013) mengemukakan bahwa buku saku yang digunakan sebagai media pembelajaran menunjukkan efektif meningkatkan motivasi belajar peserta didik sebesar 5,64\%. Wu \& Wu (2020) juga mengemukakan dalam penelitiannya bahwa mind 
mapping sangat kondusif untuk peningkatan kemampuan berpikir kritis mahasiswa.

\section{SIMPULAN}

Penelitian pengembangan buku saku ekonomi dengan konsep mind mapping sebagai pendukung bahan ajar dengan model pengembangan ADDIE mendapat kategori "sangat layak" jika digunakan dalam kegiatan pembelajaran berdasarkan hasil validasi ahli materi, media, dan grafis. Respon peserta didik juga menunjukkan buku saku ekonomi dengan konsep mind mapping praktis digunakan dalam pembelajaran. Berdasarkan hasil analisis pretest-posttest motivasi belajar ekonomi peserta didik dan uji analisis t menunjukkan bahwa buku saku ekonomi efektif untuk digunakan dalam upaya peningkatan motivasi belajar ekonomi peserta didik, namun perlu adanya uji coba lebih lanjut.

\section{DAFTAR PUSTAKA}

Agustien, A. V., \& Agung, L. (2012). Pengembangan Buku Saku Sebagai Bahan Ajar Akuntansi Pada Pokok Bahasan Jurnal Penyesuaian Perusahaan Jasa. Jurnal Pendidikan Akuntansi (JPAK), 2(2), 16.

Azhar, A. (2011). Bahan Ajar Media Pembelajaran. Jakarta: PT RajaGrafindo Persada.

Bystrova, T., \& Larionova, V. (2015). Use of Virtual Mind Mapping to Effectively Organise the Project Activities of Students at the University. Procedia Social and Behavioral Sciences, 214, 465-472. https://doi.org/10.1016/j.sbspro.2015.11.724

Davies, M. (2011). Concept Mapping, Mind Mapping and Argument Mapping: What are the differences and do they matter? Higher Education, 62(3), 279301. https://doi.org/10.1007/s10734-010-9387-6

KBBI. (2016). Kamus Besar Bahasa Indonesia. Retrieved from https://kbbi.kemdikbud.go.id

Pramika, D., \& Putri, D. N. A. O. (2013). Meningkatkan Hasil Belajar Mahasiswa Melalui Penerapan Metode Pembelajaran Peer Tutoring dengan Bantuan Media Pembelajaran Buku Saku Matematika Ekonomi. Economic Education Analysis Journal, 2(1), 18-23. https://doi.org/10.15294/eeaj.v8i2.31508

Pramika, D., \& Widalismana, M. (2018). Buku Saku Sebagai Media Pembelajaran Matematika Ekonomi Di Program Studi Pendidikan Akuntansi FKIP Universitas PGRI Palembang. Jurnal Pendidikan Ekonomi UM Metro, 6(1), 1-12.

Presiden Republik Indonesia. (2005). Peraturan Pemerintah Republik Indonesia No. 19 Tahun 2005. Jakarta: Pemerintah Indonesia.

Qurrota'Aini, S. S., \& Sukirno. (2013). Pocketbook As Media Of Learning To Improve Students' Learning Motivation. Jurnal Pendidikan Akuntansi, 11(2), 68-75.

https://doi.org/https://doi.org/10.21831/jpai.v11i2.1
692

Rayanto, Y. H., \& Sugianti. (2020). Penelitian Pengembangan Model ADDIE dan R2D2: Teori dan Praktek. Pasuruan: Lembaga Academic \& Research Institute.

Sadiman. (2014). Media Pendidikan: Pengertian, Pengembangan, dan Pemanfaatannya. Jakarta: Grafindo Persada.

Santi, N. W. A., Haryono, A., \& Sunaryanto. (2017). Pengembangan Economics Pocket Book Berbasis Quantum Learning Untuk Siswa Sekolah Menengah Atas. Jurnal Pendidikan, 2(4), 478-486.

Saputra, M., Abidin, T. F., Ansari, B. I., \& Hidayat, M. (2018). The Feasibility of An Android-Based Pocketbook As Mathematics Learning Media In Senior High SchoolThe Feasibility of An AndroidBased Pocketbook As Mathematics Learning Media In Senior High School. Journal of Physics: Conference Series, 1088, 1-6. https://doi.org/10.1088/1742-6596/1088/1/012056

Stokhof, H., de Vries, B., Bastiaens, T., \& Martens, R. (2019). Mind Map Our Way into Effective Student Questioning: a Principle-Based Scenario. Research in Science Education, 49(2), 347-369. https://doi.org/10.1007/s11165-017-9625-3

Sugiyono, P. D. (2014). Metode Penelitian Kuantitatif, Kualitatif, dan $R \& D$. Bandung: CV ALFABETA.

Suhaimi, I., \& Hakim, L. (2013). Pengembangan Buku Saku Akuntansi Sebagai Bahan Ajar Untuk Meningkatkan Motivasi Belajar Akuntansi Bagi Siswa Kelas XI Akuntansi Di SMKN 1 Sooko Mojokerto. Jurnal Pendidikan Akuntansi (JPAK), 8(1), 58-63.

Susanti, L. (2019). Strategi Pembelajaran Berbasis Motivasi. Jakarta: PT Elex Media Komputindo.

Wu, H., \& Wu, Q. (2020). Impact of Mind Mapping on The Critical Thinking Ability of Clinical Nursing Students and Teaching Application. Journal of International Medical Research, 48(3), 1-8. https://doi.org/10.1177/0300060519893225 